\title{
ZDOLNOŚĆ GOSPODARSTW ROLNYCH DO ROZWOJU W ZALEŻNOŚCI OD KIERUNKU PRODUKC.JI
}

Celem badań była ocena możliwości rozwoju gospodarstw rolnych o różnych kierunkach produkcji. Badaniem objęto gospodarstwa rolne znajdujące się w systemie FADN w 2010 i w 2013 r. Analizy prowadzono z uwzględnieniem następujących typów produkcyjnych gospodarstw rolnych: uprawy polowe, krowy mleczne, trzoda chlewna i mieszane. Zdolność gospodarstw rolnych do rozwoju oceniono na podstawie: dochodu z rodzinnego gospodarstwa rolnego, wartości nadwyżki na samofinansowanie. Zastosowano również wybrane metody analizy finansowej. O procesach odnowy majątku trwałego informuje wartość inwestycji netto. W celu określenia perspektyw funkcjonowania gospodarstw w dłuższej perspektywie, obliczono stope reprodukcji majątku trwałego. Oceniono również zdolność gospodarstw do regulowania bieżących zobowiązań. Wyniki badań wskazują, że zdolnością do reprodukcji majątku trwałego i rozwoju charakteryzują się głównie gospodarstwa specjalistyczne, chociaż w badanym okresie te możliwości były zmienne. Dysponowały one dochodem pozwalającym na wygospodarowanie nadwyżki na samofinansowanie, wartość inwestycji netto i stopa reprodukcji środków trwałych były dodatnie. Nadwyżka na samofinansowanie rozwoju gospodarstw ma charakter potencjalny, o ostatecznym jej rozdysponowaniu decydują sami rolnicy. W najtrudniejszej sytuacji były gospodarstwa o niesprecyzowanych kierunkach produkcji. Nadwyżka na samofinansowanie rozwoju w tych gospodarstwach przyjęła wartość ujemna, nie posiadały one środków na rozwój. W obu okresach badawczych wartość inwestycji netto była ujemna, co oznacza dekapitalizację majątku trwałego i proces ten ma charakter trwały.

Słowa kluczowe: aktywa trwałe, gospodarstwo, reprodukcja, rozwój, specjalizacja.

\section{WPROWADZENIE}

Gospodarstwo rolne jako komponent rolnictwa jest uczestnikiem rynku i jak każdy inny podmiot poddane jest konkurencji. Aby sprostać tym wyzwaniom musi ono posiadać potencjał konkurencyjny. Zdolność do budowania tego potencjału warunkowana jest wieloma czynnikami. Wśród tych czynników wymienia się działalność inwestycyjną i możliwości rozwoju gospodarstw rolnych. Inwestowanie, powiększanie zasobów gospodarstw

${ }^{1}$ Dr hab. inż. Zofia Kołoszko-Chomentowska, Politechnika Białostocka, ul. Wiejska 45A, 15-351 Białystok, tel. 85/746 98 53, e-mail: z.koloszko@pb.edu.pl

2 Dr hab. prof. nadzw. Zbigniew Korzeb, Politechnika Białostocka, ul. Wiejska 45A, 15-351 Białystok, tel. 85/74698 53, e-mail: z.korzeb@pb.edu.pl

${ }^{3}$ Dr Barbara Wojsznis, Politechnika Białostocka, ul. Wiejska 45A, 15-351 Białystok, tel. 85/746 98 53, e-mail: b.wojsznis@pb.edu.pl 
rolnych świadczą o możliwościach rozwojowych ${ }^{4}$. Jest to o tyle ważne, że sprawne i efektywne funkcjonowanie gospodarstw rolnych nie jest możliwe bez wprowadzania innowacyjnych rozwiązań, inwestowania w trwałe środki produkcji. Chodzi o takie inwestycje, które przyczyniają się do poprawy efektywności ogółu czynników produkcji. Możliwości rozwoju gospodarstw rolnych zależą głównie od dochodu z rodzinnego gospodarstwa rolnego. Im wyższy jest jego poziom, tym większa skłonność rolników do inwestowania w środki trwałe, do wprowadzania innowacyjnych rozwiązań. Jest on stosowany do oceny opłaty czynników produkcji rolniczej, w tym wydajności pracy w gospodarstwie rolnym w kontekście zarówno zdolności do reprodukcji rozszerzonej, a więc zdolności do rozwoju, jak i zdolności do utrzymania rodziny rolniczej5. Badania wskazują na wzrost dochodów rolniczych po wejściu do UE, a tym samym wzrost możliwości rozwoju gospodarstw. O ile przed $2004 \mathrm{r}$. około 25 tys. gospodarstw wykazywało cechy konkurencyjności, to w drugiej połowie pierwszej dekady obecnego stulecia funkcjonowało około 295 tys. gospodarstw, charakteryzujących się zdolnościami konkurencyjnymi ${ }^{6}$.

Funkcjonowanie w ramach Wspólnej Polityki Rolnej zwiększyło możliwości pozyskiwania środków na realizację działań inwestycyjnych. Strumień środków z tego tytułu jest bardzo szeroki, a ich wykorzystanie zależy głównie od aktywności rolników w pozyskiwaniu i spożytkowaniu tych środków. Z badań wynika, że występuje regionalne zróżnicowanie wykorzystania dotacji przeznaczonych na działania inwestycyjne $\mathrm{i}$ jest to zjawisko trwałe ${ }^{7}$. Korzystający $\mathrm{z}$ tych środków osiągają wyższą efektywność produkcji i zdolność do reprodukcji rozszerzonej ${ }^{8}$. Występują różnice w zakresie procesów reprodukcji majątku przede wszystkim ze względu na wielkość ekonomiczną gospodarstwa, ale też ze względu na kierunek produkcji ${ }^{9}$. Na ogół działalnością inwestycyjną częściej zainteresowane są gospodarstwa specjalistyczne. W tym kontekście, jako cel pracy przyjęto ocenę możliwości rozwoju gospodarstw rolnych o różnych kierunkach produkcji.

\section{MATERIAL I METODYKA}

Temat opracowano na podstawie danych $\mathrm{z}$ gospodarstw rolnych znajdujących się w systemie FADN. Metody oceny możliwości rozwojowych gospodarstw rolnych są bardzo różne. Jednym ze sposobów oceny tych zdolności jest obliczenie tzw. nadwyżki na

${ }^{4}$ W. Józwiak, Strategia postepowania posiadaczy gospodarstw rolnych i ich pozarolnicze formy aktywności gospodarczej w latach 1996-2002, ,Roczniki Naukowe SERiA” 2004/6(3), s. 94-100.

5 J.S. Zegar, Dochody $w$ rolnictwie $w$ okresie transformacji $i$ integracji europejskiej, Warszawa 2008.

${ }^{6}$ W. Józwiak, Przedsiębiorstwo i gospodarstwo rolne wobec zmian klimatu i polityki rolnej, Program Wieloletni 2015-2019, Warszawa 2016.

7 R. Pietrzykowski, L. Wicki, Regionalne zróżnicowanie wykorzystania środków z programów Wspólnej Polityki Rolnej na modernizację rolnictwa, ,Roczniki Nauk Rolniczych G” 2011/98(4), s. 7-22.

${ }^{8}$ P. Kobus, Zmiany $w$ dynamice skladowych dochodu rolniczego $w$ krajach czlonkowskich Unii Europejskiej po rozszerzeniu w 2004 r., „Roczniki Naukowe SERiA” 2009/1(2), s. 110-114; [w:] Czubak, M. Mikołajczak, Znaczenie inwestycji wspólfinansowanych środkami Unii Europejskiej w modernizacji rolnictwa $w$ Polsce, „Roczniki Naukowe SERiA” 2012/14(3), s. 42-46; D. Kusz, Egzogeniczne i endogeniczne uwarunkowania procesu modernizacji rolnictwa, „Roczniki Ekonomii Rolnictwa i Rozwoju Obszarów Wiejskich”2012/99(2), s. 53-67.

${ }^{9}$ A. Grzelak, Ocena procesów reprodukcji majątku gospodarstw rolnych prowadzacych rachunkowość rolna (FADN), „Zagadnienia Ekonomiki Rolnej” 2014/340(3), s. 45-64. 
samofinansowanie rozwoju ${ }^{10}$. Punktem wyjścia do jej obliczenia jest dochód brutto, rozumiany jako suma dochodu z rodzinnego gospodarstwa rolnego (SE420) i amortyzacji (SE360)._Tak obliczona wielkość powinna pokryć przynajmniej koszty pracy własnej oraz raty kredytu. Koszty pracy własnej (SE015) oszacowano na podstawie wynagrodzenia za pracę najemną. W przypadku danych FADN przyjęto je według formuły: (SE360/SE020)xSE015. W obliczeniach pominięto wartość rat kredytów z uwagi na niemożliwość ich określenia na podstawie dostępnych informacji. Nadwyżka na samofinansowanie rozwoju gospodarstw ma charakter potencjalny, o ostatecznym jej rozdysponowaniu decydują sami rolnicy.

Zastosowano również wybrane metody analizy finansowej ${ }^{11}$. W celu określenia perspektyw funkcjonowania gospodarstw, obliczono stopę reprodukcji majątku trwałego. Jest to jeden ze sposobów oceny odtwarzania środków trwałych i rozwoju gospodarstw. Wskaźnik ten obliczono według formuły: (inwestycje netto/aktywa trwałe)x 100\%, który według FADN przyjmuje postać: (SE521/SE441)x 100\%. Informuje on o rodzaju reprodukcji występującej w gospodarstwie (rozszerzona, prosta, zawężona). Oceniono również zdolność gospodarstw do regulowania bieżących zobowiązań na podstawie wskaźnika płynności bieżącej zgodnie z formułą: aktywa bieżące/zobowiązania bieżące, który przy zastosowaniu danych FADN przyjmuje postać: SE465/SE495. Zgodnie z przyjętym celem, analizy prowadzono $\mathrm{z}$ uwzględnieniem następujących typów produkcyjnych gospodarstw rolnych: uprawy polowe, krowy mleczne, trzoda chlewna i mieszane. Zakres analizy obejmuje dwa momenty czasowe: 2010 i 2013 r. Chodziło bowiem o zbadanie, czy możliwości rozwoju zmieniają się w czasie.

\section{WYNIKI}

Typ produkcyjny gospodarstwa jest czynnikiem determinującym wyposażenie gospodarstw w czynniki produkcji (tabela 1). Największe zasoby ziemi posiadają gospodarstwa specjalizujące się w uprawach polowych. Powierzchnia użytków rolnych tych gospodarstw jest o 9 ha wyższa niż w gospodarstwach specjalizujących się w produkcji trzody chlewnej i ponad 10 ha wyższa niż w gospodarstwach pozostających bez specjalizacji.

Tabela_1. Potencjał produkcyjny różnych typów produkcyjnych gospodarstw rolnych w 2013 r.

\begin{tabular}{|l|c|c|c|c|}
\hline \multicolumn{1}{|c|}{ Wyszczególnienie } & $\begin{array}{c}\text { Uprawy } \\
\text { polowe }\end{array}$ & $\begin{array}{c}\text { Krowy } \\
\text { mleczne }\end{array}$ & $\begin{array}{c}\text { Trzoda } \\
\text { chlewna }\end{array}$ & Mieszane \\
\hline Powierzchni UR (ha) & 29,5 & 21,0 & 20,4 & 18,6 \\
\hline Nakłady pracy ogółem (AWU) & 1,57 & 1,80 & 1,64 & 1,69 \\
\hline Nakłady pracy własnej (FWU) & 1,32 & 1,76 & 1,55 & 1,49 \\
\hline Aktywa ogółem (zł·ha $\left.{ }^{-1}\right)$ & 27545 & 42482 & 47767 & 32885 \\
\hline Aktywa trwałe (zł·ha $\left.{ }^{-1}\right)$ & 24042 & 38077 & 41171 & 27932 \\
\hline Kapitał własny (zł·ha $\left.{ }^{-1}\right)$ & 25211 & 40196 & 44551 & 31554 \\
\hline
\end{tabular}

Źródło: obliczenia własne na podstawie danych FADN.

${ }^{10}$ T. Sobczyński, Wplyw wielkości ekonomicznej gospodarstw rolniczych UE na ich możliwości rozwojowe, „Zeszyty Naukowe SGGW Problemy Rolnictwa Światowego” 2009/9, s. 159-168.

11 W. Gabrusewicz, Podstawy analizy finansowej, wyd. 2, Warszawa 2007. 
We wszystkich gospodarstwach dominują nakłady pracy własnej rolnika i jego rodziny, praca najemna stanowi niewielkie jej uzupełnienie. Pod względem nasycenia ziemi kapitałem najsłabiej wypadają gospodarstwa o specjalizacji uprawy polowe. W stosunku do gospodarstw najlepiej wyposażonych w aktywa trwałe, a więc specjalizujących się w produkcji trzody chlewnej różnica wynosi ponad 70\%. Również duże różnice dotyczą nasycenia ziemi kapitałem własnym.

Podstawową kategorią ekonomiczną jest dochód z rodzinnego gospodarstwa rolnego, od którego zależy konkurencyjność tych podmiotów. Wartość dochodu w odniesieniu do gospodarstwa zależy od kierunku produkcji i od wielkości gospodarstwa i nie daje pełnego obrazu sytuacji ekonomicznej rodziny rolniczej. Bardziej obiektywny obraz otrzymamy odnosząc poziom dochodu na osobę pełnozatrudnioną $w$ gospodarstwie rolnym. $\mathrm{Z}$ tego punktu widzenia najkorzystniej wypadają gospodarstwa specjalistyczne (tabela 2).

Tabela 2. Wskaźniki oceny zdolności gospodarstw rolnych do rozwoju

\begin{tabular}{|c|c|c|c|c|}
\hline Wyszczególnienie & $\begin{array}{l}\text { Uprawy } \\
\text { polowe }\end{array}$ & $\begin{array}{l}\text { Krowy } \\
\text { mleczne }\end{array}$ & $\begin{array}{l}\text { Trzoda } \\
\text { chlewna }\end{array}$ & Mieszane \\
\hline \multicolumn{5}{|c|}{$2010 \mathrm{r}}$. \\
\hline $\begin{array}{l}\text { Dochód z rodzinnego gospodar- } \\
\left.\text { stwa rolnego (zł·gosp. }{ }^{-1}\right)\end{array}$ & 92600 & 45573 & 53152 & 27911 \\
\hline $\begin{array}{l}\text { Dochód } \mathrm{z} \text { rodzinnego gospodar- } \\
\text { stwa rolnego }\left(\mathrm{z} \cdot F W U^{-1}\right)\end{array}$ & 57931 & 26929 & 34379 & 17474 \\
\hline Nadwyżka na samofinansowanie & 82328 & 3430 & 34790 & -2239 \\
\hline \multicolumn{5}{|c|}{$2013 \mathrm{r}$. } \\
\hline $\begin{array}{l}\text { Dochód z rodzinnego gospodar- } \\
\text { stwa rolnego }\left(\mathrm{zł} \cdot \text { gosp. }^{-1}\right)\end{array}$ & 48010 & 61964 & 69688 & 25218 \\
\hline $\begin{array}{l}\text { Dochód } \mathrm{z} \text { rodzinnego gospodar- } \\
\text { stwa rolnego }\left(\mathrm{z} \cdot \mathrm{FWU}^{-1}\right)\end{array}$ & 33083 & 35225 & 43387 & 16741 \\
\hline Nadwyżka na samofinansowanie & 25164 & 49097 & 46624 & -27345 \\
\hline
\end{tabular}

Źródło: obliczenia własne na podstawie danych FADN.

W 2010 r. gospodarstwa specjalizujące się w uprawach polowych, osiągnęły najwyższy poziom dochodu na osobę pełnozatrudnioną i był on ponad trzykrotnie wyższy niż w gospodarstwach typu mieszane. W 2013 r. wartość omawianego wskaźnika wzrosła tylko w gospodarstwach typu krowy mleczne i trzoda chlewna. Niezależnie od zmian warunków gospodarowania, najniższy dochód generowały gospodarstwa pozostające bez specjalizacji. Zatem nadwyżka na samofinansowanie rozwoju w tych gospodarstwach przyjęła w obu okresach badawczych wartość ujemna, co oznacza, że nie posiadały one środków na rozwój. Natomiast wszystkie typy gospodarstw specjalistycznych generowały dochód na poziomie pozwalającym na wygospodarowanie nadwyżki na samofinansowanie. Poziom tej nadwyżki był zróżnicowany, ale też nie oznacza, że środki te zostały wykorzystane na zwiększenie aktywów trwałych. Obliczona nadwyżka oznacza wyłącznie potencjalne możliwości powiększenia majątku trwałego gospodarstw rolnych. W rzeczywistości jej zagospodarowanie zależy od indywidualnej sytuacji każdego gospodarstwa. 
O procesach odnowy majątku trwałego informuje wartość inwestycji netto (skorygowana o wartość amortyzacji). W 2010 r. dodatnią wartością inwestycji charakteryzowały się tylko gospodarstwa typu uprawy polowe i krowy mleczne. W przypadku gospodarstw wyspecjalizowanych w produkcji roślinnej wystąpiła nawet reprodukcja rozszerzona (stopa reprodukcji aktywów trwałych wynosiła 1,41\%). W 2013 r. warunki reprodukcji zmieniły się i dodatnia wartość inwestycji netto zanotowano tylko w gospodarstwach wyspecjalizowanych w produkcji zwierzęcej, przy czym w gospodarstwach z trzodą chlewną była ona ponad 4-krotnie wyższa niż w gospodarstwach mlecznych. W pozostałych typach gospodarstw wartość inwestycji netto był ujemna, co oznacza dekapitalizację mająt$\mathrm{ku}$ trwałego. Potwierdza to również stopa reprodukcji aktywów trwałych, która przyjęła wartość ujemną.

Należy zwrócić uwage na zmiany, jakie dokonały się w gospodarstwach z trzodą chlewną. W 2010 r. gospodarstwa te nie posiadały zdolności odtwarzania majątku trwałego, wystąpiło szybsze zużycie środków trwałych niż tempo ich odtwarzania. Natomiast w 2013 r. gospodarstwa te już osiągnęły dodatnią wartość inwestycji netto i stopę reprodukcji aktywów trwałych. W najtrudniejszej sytuacji są gospodarstwa o niesprecyzowanych kierunkach produkcji. W obu okresach badawczych wartość inwestycji netto była ujemna, co oznacza, że nastąpiła w nich dekapitalizacja majątku trwałego i proces ten ma charakter trwały.

O zdolności gospodarstwa do funkcjonowania na rynku informuje również wskaźnik płynności finansowej. Z danych przedstawionych w tabeli 3 wynika, że we wszystkich grupach gospodarstw wskaźnik bieżącej płynności finansowej odbiegał od wartości optymalnych $(1,5-2,0)$. Trudno jest o jednoznaczną ocenę tego zjawiska, ponieważ przyczyn może być wiele. $Z$ rachunkowego punktu widzenia można wnioskować, że skala inwestowania była zbyt mała. $Z$ drugiej strony nie można zapominać, że możliwości inwestowania zależą głównie od poziomu dochodu, który ostatecznie przesądza o możliwościach spłaty zobowiązań wynikajacych głównie z zaciagniętego na cele inwestycyjne kredytu. Z badań wynika, że w większości gospodarstw rolnych występuje „,nadpłynność”, wynikająca z ostrożnego podejścia do inwestowania i korzystania z zewnętrznych źródeł finansowania $^{12}$.

Współczesne koncepcje dotyczące przyszłości gospodarstw rolnych zakładaja rozwój zrównoważony, a więc uwzględniający cele ekonomiczne, ekologiczne i społeczne. W przypadku gospodarstw towarowych, o dużej skali produkcji, najczęściej mamy do czynienia z maksymalizowaniem efektów ekonomicznych. Jest to możliwe dzięki wprowadzeniu nowych technologii, które pozwalają na wzrost intensywności i zdolności produkcyjnych. Jednak taki model rozwoju napotyka bariery wynikające z ograniczeń środowiskowych. Wskaźnikiem informującym o intensywności produkcji jest zużycie pośrednie. Jednocześnie jest to wskaźnik obciążenia środowiska środkami produkcji. Biorąc zatem pod uwagę wartość zużycia pośredniego należy zauważyć, że zmiany intensywności produkcji w czasie wskazują na zwiększenie obciążenia środowiska środkami produkcji w gospodarstwach wszystkich typów.

${ }^{12}$ T. Hertz, The effect of nonfarm income on investment in Bulgarian family farming, „Agricultural Economics" 2009/40(2), p. 161-176. 
Tabela 3. Wartość inwestycji w różnych typach produkcyjnych gospodarstw rolnych w latach 2010 i 2013

\begin{tabular}{|l|c|c|c|c|}
\hline \multicolumn{1}{|c|}{ Wyszczególnienie } & $\begin{array}{c}\text { Uprawy } \\
\text { polowe }\end{array}$ & $\begin{array}{c}\text { Krowy } \\
\text { mleczne }\end{array}$ & $\begin{array}{c}\text { Trzoda } \\
\text { chlewna }\end{array}$ & Mieszane \\
\hline \multicolumn{5}{|c|}{$2010 \mathrm{r}$. } \\
\hline Inwestycje brutto (zł) & 40614 & 19803 & 18620 & 8666 \\
\hline Amortyzacja (zł) & 28016 & 18116 & 19530 & 12592 \\
\hline Inwestycje netto (zł) & 12598 & 1687 & -910 & -3927 \\
\hline $\begin{array}{l}\text { Stopa reprodukcji aktywów } \\
\text { trwałych (\%) }\end{array}$ & 1,41 & 0,28 & $-0,14$ & $-0,93$ \\
\hline Wskaźnik płynności bieżącej & 5,10 & 5,37 & 6,68 & 8,35 \\
\hline Zużycie pośrednie (zł·ha ${ }^{-1}$ ) & 2164 & 3285 & 6966 & 2911 \\
\hline \multicolumn{5}{|l|}{2013 r. } \\
\hline Inwestycje brutto (zł) & 21164 & 25708 & 33537 & 12613 \\
\hline Amortyzacja (zł) & 21374 & 24008 & 25978 & 17711 \\
\hline Inwestycje netto (zł) & -210 & 1701 & 7559 & -5099 \\
\hline $\begin{array}{l}\text { Stopa reprodukcji aktywów } \\
\text { trwałych (\%) }\end{array}$ & $-0,03$ & 0,21 & 0,90 & $-0,98$ \\
\hline Wskaźnik płynności bieżącej & 6,75 & 8,47 & 7,89 & 10,34 \\
\hline Zużycie pośrednie (zł·ha ${ }^{-1}$ ) & 2750 & 3949 & 9922 & 4579 \\
\hline
\end{tabular}

Źródło: obliczenia własne na podstawie danych FADN.

\section{PODSUMOWANIE}

Problematyka przyszłości rolnictwa, podejmowana w wielu pracach badawczych, jest ciągle aktualna. To zainteresowanie wynika głównie z potrzeby zagwarantowania bezpieczeństwa żywnościowego naszego kraju i dostosowania gospodarstw rolnych do warunków konkurencji. Dotychczasowe działania związane z realizacją Wspólnej Polityki Rolnej świadczą o realizacji zrównoważonego rozwoju tego działu gospodarki. Wyrazem tego jest z jednej strony umacnianie gospodarstw najsilniejszych, zdolnych do konkurencji na rynku krajowymi zagranicznym, a z drugiej strony wspieranie gospodarstw nieefektywnych, wypełniających nowe pozarolnicze funkcje.

Przeprowadzona analiza możliwości rozwoju gospodarstw rolnych wskazuje, że postępuje proces wzmocnienia jednostek o dużym potencjale produkcyjnym. Są to gospodarstwa specjalistyczne podejmujące działania inwestycyjne, służące budowaniu potencjału produkcyjnego. W badanym okresie możliwością samofinansowania rozwoju charakteryzowały się wyłącznie gospodarstwa specjalistyczne, chociaż nie zawsze wystąpiła reprodukcja rozszerzona Wynika to zarówno z zewnętrznych warunków gospodarowania (wrażliwość na zmiany koniunktury gospodarczej), jak i osobistej sytuacji rolnika i jego rodziny. Jednak w tych gospodarstwach nie zaobserwowano dekapitalizacji majątku. Daje to podstawy do prognozowania o dalszym procesie modernizacji gospodarstw specjalistycznych i ich rozwoju w przyszłości. W najtrudniejszej sytuacji są gospodarstwa typu mieszane, w których obserwuje się trwałą niezdolność do reprodukcji majątku. W obu okresach badawczych wartość inwestycji netto była ujemna, co oznacza dekapitalizację 
majątku trwałego. Gospodarstwa te pełnią inne funkcje niż produkcyjna i wymagają odmiennych form wsparcia ze środków publicznych.

\section{LITERATURA}

[1] Czubak W., Mikołajczak M., Znaczenie inwestycji wspólfinansowanych środkami Unii Europejskiej $w$ modernizacji rolnictwa w Polsce, „Roczniki Naukowe SERiA” 2012/14(3).3.

[2] Hertz T., The effect of nonfarm income on investment in Bulgarian family farming, "Agricultural Economics" 2009/40(2)2. http://onlinelibrary.wiley.com/doi/10.1111/j.15740862.2009.00367.x/full (dostęp: 25.05.2016 r.).

[3] Józwiak W., Strategie postępowania posiadaczy gospodarstw rolnych i ich pozarolnicze formy aktywności gospodarczej w latach 1996-2002, ,Roczniki Naukowe SERiA” 2004/ $6(3)$.

[4] Józwiak W., Przedsiębiorstwo i gospodarstwo rolne wobec zmian klimatu i polityki rolnej, Program Wieloletni 2015-2019, Wyd. IERiGŻ-PIB, Warszawa 2016.

[5] Gabrusewicz W., Podstawy analizy finansowej, wyd. II, Polskie Wydawnictwo Ekonomiczne, Warszawa 2007.

[6] Grzelak A., Ocena procesów reprodukcji majątku gospodarstw rolnych prowadzacych rachunkowość rolna (FADN), ,Zagadnienia Ekonomiki Rolnej” 2014/340(3).

[7] Kobus P., Zmiany w dynamice składowych dochodu rolniczego w krajach czlonkowskich Unii Europejskiej po rozszerzeniu w 2004 r., ,Roczniki Naukowe SERiA”2009/11(2).

[8] Kusz D., Egzogeniczne i endogeniczne uwarunkowania procesu modernizacji rolnictwa, „Roczniki Ekonomii Rolnictwa i Rozwoju Obszarów Wiejskich” 2012/99(2).

[9] Pietrzykowski R., Wicki L., Regionalne zróżnicowanie wykorzystania środków z programów Wspólnej Polityki Rolnej na modernizację rolnictwa, „Roczniki Nauk Rolniczych G” 2011/98(4)

[10] Sobczyński T., Wplyw wielkości ekonomicznej gospodarstw rolniczych UE na ich możliwości rozwojowe, „Zeszyty Naukowe SGGW Problemy Rolnictwa Światowego” 2009/9.

[11] Zegar J.S., Dochody w rolnictwie w okresie transformacji i integracji europejskiej, Wyd. IERiGŻ-PIB, Warszawa 2008.

Sformatowano: Angielski (Stany

Zjednoczone)

Sformatowano: Angielski (Stany

Zjednoczone)

\section{AN ABILITY OF FARM'S DEVELOPMENT DEPENDING ON THE DIRECTION OF PRODUCTION}

The purpose of the research was to evaluate the development abilities of farms with different direction of production. Farms within FADN system from the years 2010 and 2013 were incorporated within the project. The analyzes were carried out according to the following production types: field crops, milk, pigs, mixed. The ability of the development of farms was evaluated on the level of: income from family farms, value of the surplus for self-financing, Selected methods of financial analysis were also applied. In order to determine the perspectives of the functioning of farms, the rate of reproduction of fixed assets' rate was calculated. The ability of regulating current liabilities was also assessed. The results of the examination show that the ability of reproduction of fixed assets and development are mostly represented by specialized farms, although those abilities within the examined period of time were variable. They had an income that allowed them for surplus on self-financing, the net value of the investment and the reproduction of fixed assets' rate was favourable. The

\section{Usunięto:}


surplus for self-financing of the development of the farms is potential value , and the final distribution of the farm income is depended by the farmers themselves. The farms with nonspecified directions of production were in the most difficult situation. The surplus for the self-financing of development in these farms was negative, and farms did not have funds for development. In both examination periods, the net value of the investments was negative, which means decapitalization of the fixed assets with the constant character of the process.

Keywords: fixed assets, farm, reproduction, development, specialization.

\section{DOI: 10.7862/rz.2017.mmr.5}

Sformatowano: Czcionka:

Tekst złożono $w$ redakcji: listopad $2016 r$.

Przyjęto do druku: marzec 2017 r. 